\title{
Some observations on complement-fixing antibodies to the EB virus
}

\author{
R. N. P. SUTTON, S. D. MARSTON, AND R. T. D. EMOND \\ From the Department of Medical Microbiology, King's College Hospital Medical School, London, and the \\ Royal Free Hospital Infectious Diseases Unit, Coppetts Wood Hospital, London
}

SYNOPSIS Complement-fixing antibodies against an antigen prepared from the EB3 line of cultured Burkitt tumour cells were studied in various groups of patients and control individuals. Higher antibody titres were observed in patients with Burkitt's tumour than in African patients with other diagnoses. Significantly more medical students and nurses with a history of infectious mononucleosis possessed antibodies than those with no such history. Low levels of antibody were observed in patients during the acute phase of infectious mononucleosis and these levels were significantly lower than those in patients admitted to the same hospital with other diagnoses.

During the early months following the acute phase of illness, EB complement-fixing antibodies remained stationary or apparently declined in titre but, in patients tested one or more years later, significantly higher antibody levels were observed.

Since Epstein, Achong, and Barr (1964) demonstrated the presence of a herpes-like virus (the EB virus) in cultured Burkitt tumour cells, many workers have investigated the significance of antibodies to this virus. Thus antibodies have been found in sera from patients with Burkitt tumours and in apparently normal individuals (Henle and Henle, 1966) and, more recently, an association has been recognized between the development of antibodies to the EB virus and infection with infectious mononucleosis (Niederman, McCollum, Henle, and Henle, 1968). Immunofluorescent techniques have been used in almost all these studies and complement-fixing antibodies, although described (Armstrong, Henle, and Henle, 1966; Henle and Henle, 1966; Gerber and Birch, 1967), have not been employed to any great extent. In the following report, we outline our initial experience with a complement-fixing antigen prepared from cultured Burkitt tumour cells and suggest that this may provide an additional tool in the investigation of EB virus infections.

\section{Methods}

Sera were obtained from healthy medical students and nurses at the beginning of their hospital training, who also completed a questionnaire in which they were asked whether they had ever had infectious mononucleosis or glandular fever. In the present

Received for publication 1 April 1971. study, we only include those born in Europe or North America as preliminary observations suggested considerable differences in antibody levels and in history of illness between those born in temperate climates and those born in the tropics.

Sera were also taken from patients admitted to the Royal Free Hospital Infectious Diseases Unit, Coppetts Wood Hospital, London. Infectious mononucleosis was diagnosed in some of these patients, the criteria for diagnosis being clinical, together with a positive serological test and the presence of typical abnormal cells in the peripheral blood. Patients admitted to the same hospital with other diagnoses formed a control group. Sera from these patients were tested blindly and the diagnosis was not disclosed until the serological result had been reported. Sera were also obtained from patients admitted to hospitals of the King's College Hospital group. Sera from patients with Burkitt's tumour and from African control patients, matched as far as possible for age and sex, were obtained from the University Hospitals at Makerere and Ibadan. All sera were stored without preservative at $-20^{\circ} \mathrm{C}$.

SEROLOGICAL METHODS

The EB3 cell line was used as a source of antigen. This line had been obtained from Professor Epstein in 1968 and was subsequently cultured in Eagle's MEM $(78 \%)$, foetal calf serum $(20 \%), 200 \mathrm{mM}$ glutamine $(1 \%)$, and non-essential amino-acids $(1 \%)$ with added antibiotics. The cells were grown in $\mathbf{2 5 0}$ 
$\mathrm{ml}$ flasks, $100 \mathrm{ml}$ of cell suspension to each flask, and were incubated at $37^{\circ} \mathrm{C}$. An antigen was prepared by adjusting the cell count to $2 \times 10^{7}$ cells $/ \mathrm{ml}$ and disrupting the cells by four cycles of freezing and thawing, the antigen being then clarified by centrifugation. In some early experiments, the cells were 'aged' (Old, Boyse, Oettgen, de Harven, Geering, Williamson, and Clifford, 1966) by holding them at $30^{\circ} \mathrm{C}$ for some days before antigen preparation but, as this gave no apparent advantage in antigen yield, in the majority of cases the cells were incubated throughout at $37^{\circ} \mathrm{C}$. The micro-method of Takatsy (1953) as adapted and modified by Sever, Ley, Wolfman, Caplan, Pernell, Crockett, and Turner (1964) was used in complement-fixation tests. Sera were tested in batches of 16 to 24 .

\section{IMMUNOFLUORESCENCE}

Assay of fluorescent antibodies was carried out by the method of Henle and Henle (1966). The EB3 cell line was used as a source of cells. Sera were coded and randomised before being examined.

\section{Results}

Sera from 14 patients with Burkitt's tumour and from nine African patients with other conditions $\Rightarrow$ were tested for antibodies to the EB virus by im $-?$ munofluorescence and by complement fixation (CF). In both types of assay, antibody titres were, in general, higher in the patients with Burkitt's tumour? than in the remainder, although antibodies weres present in both groups (Table I).

Two hundred and nineteen sera from healthy medical students and nurses and from patients admitted to hospital with a variety of diagnoses $\vec{\omega}$ (other than Burkitt's tumour or infectious mononucleosis) were tested for EB complement-fixationo antibodies. A steady rise in the proportion of individuals with positive sera, ie, with titres greaterio than 4 was observed during the years of early adultio life (Table II). One hundred and fifty-three of 219adults $(70 \%)$ possessed EB complement-fixing? antibodies.

Of the 181 nurses and medical students who were included in this study, $18(10 \%)$ gave a history of previous infectious mononucleosis. Such a history appeared to be significantly associated (Table III) with the possession of EB complement-fixation $\vec{C}$ antibodies. However, 46 patients admitted to hospital with infectious mononucleosis tended to have lower EB complement-fixation antibody levelso

\begin{tabular}{|c|c|c|c|c|c|}
\hline Age (years) & Sex & Source & Diagnosis & $\begin{array}{l}\text { Fluorescent Antibody } \\
\text { Titre }\end{array}$ & $\begin{array}{l}\text { Complement-fixing } \\
\text { Antibody Titre }\end{array}$ \\
\hline $\begin{array}{l}4 \\
5 \\
5 \\
23 \\
12 \\
12 \\
7 \\
7 \text { mth } \\
8 \\
7 \\
5 \\
7 \\
3 \\
\text { NK } \\
5 \\
6 \\
9 \\
30 \\
15 \\
5 \\
14 \\
3 \\
9\end{array}$ & $\begin{array}{l}\mathbf{M} \\
\mathbf{M} \\
\mathbf{F} \\
\mathbf{M} \\
\mathbf{N K} \\
\mathbf{N K} \\
\mathbf{N K} \\
\mathbf{N K} \\
\mathbf{M} \\
\mathbf{M} \\
\mathbf{F} \\
\mathbf{F} \\
\mathbf{N K} \\
\mathbf{M} \\
\mathbf{M} \\
\mathbf{M} \\
\mathbf{M} \\
\mathbf{M} \\
\mathbf{F} \\
\mathbf{F} \\
\mathbf{M} \\
\mathbf{F}\end{array}$ & $\begin{array}{l}\text { Makerere } \\
\text { Makerere } \\
\text { Makerere } \\
\text { Makerere } \\
\text { Makerere } \\
\text { Makerere } \\
\text { Makerere } \\
\text { Ibadan } \\
\text { Ibadan } \\
\text { Ibadan } \\
\text { Ibadan } \\
\text { Ibadan } \\
\text { Ibadan } \\
\text { Makerere } \\
\text { Makerere } \\
\text { Makerere } \\
\text { Makerere } \\
\text { Makerere } \\
\text { Makerere } \\
\text { Ibadan } \\
\text { Ibadan } \\
\text { Ibadan } \\
\text { Ibadan }\end{array}$ & $\begin{array}{l}\text { Burkitt's tumour } \\
\text { Burkitt's tumour } \\
\text { Burkitt's tumour } \\
\text { Burkitt's tumour } \\
\text { Burkitt's tumour } \\
\text { Burkitt's tumour } \\
\text { Burkitt's tumour } \\
\text { Burkitt's tumour } \\
\text { Burkitt's tumour } \\
\text { Burkitt's tumour } \\
\text { Burkitt's tumour } \\
\text { Burkitt's tumour } \\
\text { Burkitt's tumour } \\
\text { Burkitt's tumour } \\
\text { Intussusception } \\
\text { Tubercular lymphadenitis } \\
\text { Hepatic cirrhosis } \\
\text { Fracture of tibia } \\
\text { Anaplastic tumour } \\
\text { Gastroenteritis } \\
\text { Nephrotic syndrome } \\
\text { Tuberculosis } \\
\text { Nephrotic syndrome }\end{array}$ & $\begin{array}{r}>640 \\
120 \\
>640 \\
>640 \\
>640 \\
120 \\
120 \\
10 \\
120 \\
>640 \\
120 \\
60 \\
120 \\
>640 \\
60 \\
15 \\
240 \\
120 \\
15 \\
240 \\
24 \\
240 \\
30\end{array}$ & $\begin{array}{r}12 \\
16 \\
<\quad 4 \\
192 \\
256 \\
8 \\
8 \\
32 \\
8 \\
16 \\
N T \\
256 \\
192 \\
N T \\
6 \\
8 \\
12 \\
24 \\
16 \\
20 \\
N T \\
<\quad 4 \\
<\quad 4\end{array}$ \\
\hline
\end{tabular}

Table I Antibodies to $E B$ virus in African patients

Antibody Levels

\section{Fluorescent}

Rank sum (control patients) $=77.2$

for $n_{1}=9 ; n_{3}=14, R=81$

$\alpha=0.05$ (significant at $5 \%$ level) 


\begin{tabular}{|c|c|c|c|}
\hline Age (years) & Source & $\begin{array}{l}\text { Number with EB Complement- } \\
\text { fixing Antibody Titres greater } \\
\text { than } 4 / \text { Total Number Tested }\end{array}$ & $\begin{array}{l}\text { Percentage of Sera with EB } \\
\text { Complement-fixing Antibody } \\
\text { Titres of } 4 \text { or less }\end{array}$ \\
\hline $\begin{array}{l}18-19 \\
20-21 \\
22-23 \\
24-28 \\
\text { Over } 25\end{array}$ & $\begin{array}{l}\text { Nurses } \\
\text { Nurses and medical students } \\
\text { Nurses and medical students } \\
\text { Nurses and medical students } \\
\text { Hospital patients (other than those } \\
\text { with infectious mononucleosis) }\end{array}$ & $\begin{array}{l}35 / 64 \\
50 / 82 \\
18 / 27 \\
6 / 8 \\
34 / 38\end{array}$ & $\begin{array}{l}54 \\
61 \\
67 \\
75 \\
89\end{array}$ \\
\hline Over 18 & Total & $153 / 219$ & 70 \\
\hline
\end{tabular}

Table II EB Complement-fixing antibodies in different age groups

\begin{tabular}{lll}
\hline & \multicolumn{2}{c}{ EB Complement-fixation Antibody Titres } \\
\cline { 2 - 3 } & 4 or Less & Greater than 4 \\
\hline $\begin{array}{l}\text { History of infectious } \\
\text { mononucleosis }\end{array}$ & 2 & 16 \\
$\begin{array}{l}\text { No history of infectious } \\
\text { mononucleosis } 68\end{array}$ & 95 \\
\hline
\end{tabular}

Table III EB complement-fixation antibodies in nurses and medical students related to their histories of previous infectious mononucleosis ${ }^{1}$

${ }^{2} \mathrm{P}=0.007$ (Fisher's exact test) (significant at $1 \%$ level)

\begin{tabular}{|c|c|c|}
\hline & \multicolumn{2}{|c|}{ EB Complement-fixation Antibody Titres } \\
\hline & 4 or Less & Greater than 4 \\
\hline $\begin{array}{l}\text { Patients with infectiou } \\
\text { mononucleosis } \\
\text { Patients with other } \\
\text { diagnoses }\end{array}$ & $\begin{array}{l}s \\
19 \\
5\end{array}$ & $\begin{array}{l}27 \\
45\end{array}$ \\
\hline
\end{tabular}

Table IV EB complement-fixation antibodies in patients admitted to Coppetts Wood Hospital ${ }^{1}$

${ }^{1} \mathbf{P}=0.0003$ (Fisher's exact test) (significant at $0.1 \%$ level)

than 50 patients admitted to the same hospital with other conditions (Table IV). The sex ratio in the two groups of hospital patients was the same but the control patients were older (mean age 30 years) than those with infectious mononucleosis (mean age 18 years). Comparison by age groups suggested that the significance of this difference was not considerably affected by this inhomogeneity; thus, in the 11-20year-old age group, 15 of 31 patients with infectious mononucleosis $(48 \%$ ) and two of 12 control patients (17\%) lacked EB complement-fixation antibodies.

We followed up 23 patients who had been admitted to hospital, eight to 22 months previously, with infectious mononucleosis and who had remained well since their discharge from hospital. Significant increases in EB complement-fixation antibody levels were observed in almost all of these patients (Table V).

\begin{tabular}{|c|c|c|}
\hline & EB Comp & ixation Antibody Titres \\
\hline & 4 or Less & Greater than 4 \\
\hline $\begin{array}{l}\text { Sera taken during acute } \\
\text { phase of infectious } \\
\text { mononucleosis (mean } 0.4 \\
\text { months after onset) }\end{array}$ & 11 & 12 \\
\hline $\begin{array}{l}\text { Sera taken following } \\
\text { recovery from infectious } \\
\text { mononucleosis (mean } 14 \cdot 4 \\
\text { months after onset) }\end{array}$ & 4 & 22 \\
\hline
\end{tabular}

Table V EB complement fixation antibodies in 23 patients with infectious mononucleosis ${ }^{1}$

${ }^{1} P=0.0008$ (Fisher's exact test significant at $0.1 \%$ level)

The EB complement-fixation antibody levels in medical students, nurses, and patients were analysed according to the time which had elapsed between the onset of infectious mononucleosis and the dates on which their sera were taken (Table VI). They were

\begin{tabular}{|c|c|c|c|}
\hline & \multicolumn{3}{|c|}{ Period Elapsed between Onset of Infectious Mononucleosis and Date of Serum } \\
\hline & 15 Days or Less & 15 Days to One Year & More than One Year \\
\hline $\begin{array}{l}\text { Number of patients } \\
\text { Geometric means of EB CF titres }\end{array}$ & $\begin{array}{l}31 \\
44 \cdot 45\end{array}$ & $\begin{array}{l}35 \\
31 \cdot 43\end{array}$ & $\begin{array}{l}38 \\
69.05\end{array}$ \\
\hline $\begin{array}{l}\text { Comparison between groups } \\
\text { (Student's } t \text { test) } \\
15 \text { days or less } \\
15 \text { days to } 1 \text { year }\end{array}$ & - & $\begin{array}{l}t=0.90 \\
0.40>P<0.30 \\
-\end{array}$ & $\begin{array}{l}t=1.43 \\
0.1>P<0.2 \\
t=2.46 \\
0.01>P<0.02\end{array}$ \\
\hline
\end{tabular}

Table VI EB Complement-fixation antibodies in patients tested at varying times after the onset of infectious mononucleosis 
arranged in three approximately equal groups for statistical reasons. The geometric mean titres of sera taken during the first year remained stationary or possibly declined but the mean titre of sera taken one year or more following illness had risen significantly.

\section{Discussion}

It has been shown convincingly (zur Hansen, Henle, Hummeler, Diehl, and Henle, 1967; Epstein and Achong, 1968) that those cells which react in the Henle and Henle (1966) type of fluorescent antibody test contain EB virus. The role of the EB virus in the complement-fixation test is not so clear and complement fixation with antigens derived from apparently virus-free cell lines has been reported (Pope, Horne, and Wetters, 1969). The essential nature of our antigen remains, therefore, an enigma. Nevertheless, we have shown that there is a relationship between development of antibodies to this antigen and a past history of infectious mononucleosis and that those patients who develop infectious mononucleosis are those without preexisting antibody. Although, in this condition, it is often difficult to define accurately the date of onset, we have evidence that the initially modest levels of EB complement-fixation antibody remain stationary or possibly decline during the early months following illness, to be followed, over one year later, by a statistically significant rise in geometric mean titre. These observations are consonent with the hypothesis that episodes of clinical infectious mononucleosis are primary infections with the EB virus and that subsequent re-infection, or re-activation of a latent infection, may take place, possibly in the absence of frank illness.

The variations in EB complement-fixation antibody titres which we have described have not, so far, been seen in cases studied with immunofluorescent or other tests. Further work is clearly necessary to delineate the character of the EB complementfixing antigen, its relationship to similar antigens from other cell lines, and to immunofluorescent and other antibodies.
We are grateful to Professors V. A. Ngu and M. A. H. King and to Drs D. H. Wright and A. C. Allison for sera from African patients, to Dr Hillas Smith for access to his patients, and to $\operatorname{Dr} M$. de $\mathbf{L}$. Coutinho for help in collecting specimens. Mr R. Chalke of the King's College Hospital Computer Unit kindly calculated the $t$ tests. This work was is carried out with the financial support of the Leukae- $\vec{\circ}$ mia Research Fund and of the Cancer Research Campaign.

\section{References}

Armstrong, D., Henle, G., and Henle, W. (1966). Complementfixation tests with cell lines derived from Burkitt's lymphoma and acute leukaemias. J. Bact., 91, 1257-1262.

Epstein, M. A., and Achong, B. G. (1968). Specific immunofluorescence test for the herpes-type EB virus of Burkitt lymphoblasts, authenticated by electron microscopy. J. nat. Cancer Inst., 40, 593-607.

Epstein, M. A., Achong, B. G., and Barr, Y. M. (1964). Virus particles in cultured lymphoblasts from Burkitt's lymphoma. Lancet, 1, 702-703.

Epstein, M. A., Barr, Y. M., and Achong, B. G. (1965). Studies with Burkitt's lymphoma. In Methodological Approaches to the $\vec{\nabla}$ Study of Leukaemia (Wistar Institute Symposium Monograph D No. 4) pp, 69-82. Wistar Institute Press, Philadelphia.

Gerber, P., and Birch, S. M. (1967). Complement-fixing antibodies in $\overrightarrow{0}$ sera of human and nonhuman primates to viral antigens derived from Burkitt's lvmphoma cells. Proc. nat. Acad. Sci. (Wash.), 58, 478-484.

Hausen, H. zur., Henle, W., Hummeler, K., Diehl, V., and Henle, G. (1967). Comparative study of cultured Burkitt tumor cells by immunofluorescence, autoradiography and electron microscopy. J. Virol., 1, 830-837.

Henl $=$, G., and Henle, W. (1966). Immunofluorescence in cells derived from Burkitt's lymphoma. J. Bact., 91, 1248-1256.

Henle, G., Henle, W., and Diehl, V. (1968). Relation of Burkitt's tumor-associated herpes-type virus to infectious mononucleosis. Proc. nat. Acad. Sci. (Wash.), 59, 94-101.

Niederman, J. C., McCollum, R. W., Henle, G., and Henle, W. (1968). Infectious mononucleosis: clinical manifestations in relation to EB virus antibodies. J. Amer. med. Ass., 2113, 205-209.

Old, L. J., Boyse, E. A., Oettgen, H. F., Harven, E. de, Geering, G., Williamson, B., and Clifford, P. (1966). Precipitating antibody $\overparen{O}$ in human serum to an antigen present in cultured Burkitt's lymphoma cells. Proc. nat. Acad. Sci. (Wash.), 56, 1699-1704. O

Pope, J. H., Horne, M. K., and Wetters, E. J. (1969). Significance of a complement-fixing antigen associated with herpes-like virus $?$ and detected in the Raji cell line. Nature (Lond.), 222, 186-187.

Sever, J. L., Ley, A. C., Wolman, F., Caplan, B. M., Pernell, W., Crockett, B. S., and Turner, H. C. (1964). Utilization of $O$ disposable plastic plates, with a serologic microtechnic. Amer. J. clin. Path., 41, 167-170.

Takatsy, G. (1953). The use of spiral loops in serological and virological micro-methods. Acta microbiol. Acad. Sci. hung., 3, 191-202. 